\title{
ANALISIS RASIO KEUANGAN TERHADAP PEMBAGIAN SISA HASIL USAHA PADA KOPERASI KREDIT ANUGERAH BANDARJAYA LAMPUNG TENGAH
}

\author{
Agnes Susana Merry Purwati \\ Program Studi Akuntansi Sekolah Tinggi Ilmu Ekonomi Gentiaras Lampung \\ Email: agnessusana3@gmail.com
}

\section{ABSTRACT}

Financial ratio is to be an analytical tool that have an important influence the progress and success of a company in managing its finances. For the case of the research, the Anugerah Credit Union Bandarjaya is the object to be researched by the author. In this research, the authors tooks the research variable such us Liquidity, Solvability, and Rentability Ratio based on variable Remaining of Business Results (SHU).

The purpose of the research is to find out the influence of Liquidity Ratio, Solvability Ratio, and Rentability Ratio to the result of Remaining of Business Results (SHU). The author hopes that in the next period the Anugerah Credit Union Bandarjaya can improve its efficiency and effectiveness in financial performance. This is based on the year of the research period, there is a decrease in the Remaining of Business Results (SHU).

The results of the research shows that the Liquidity Ratio (Current Ratio) has influenced positively and significantly on the Remaining of Business Results (SHU), the Solvability Ratio (Debt to Equity Ratio) has influenced positively and significantly on the Remaining of Business Results (SHU), the Rentability Ratio (Return On Equity) has influenced positively and significantly on the Remaining of Business Results (SHU). Simultaneously (together), Current Ratio (CR), Debt to Equity Ratio (DER), and Return On Equity (ROE) has influenced positively and significantly on the Remaining of Business Results (SHU) in Anugerah Credit Union Bandarjaya.

Keywords : Liquidity Ratio (Current Ratio), Solvability Ratio (Debt to Equity Ratio), Rentability Ratio (Return On Equity), Remaining of Business Results (SHU).

\section{PENDAHULUAN}

\subsection{Latar Belakang}

Lembaga sektor keuangan sangat dibutuhkan dalam mendukung permodalan dalam sektor riil, hal ini dibuktikan dengan adanya konsep perbankan, baik yang dibentuk secara konvensional maupun yang berprinsip syariah.. Berdasarkan pada amanat yang terkandung dalam Pasal 33 ayat (1) UndangUndang Dasar 1945 menyatakan bahwa perekonomian Indonesia disusun sebagai usaha bersama atas asas kekeluargaan. Dalam penjelasan pasal ini menyatakan bahwa kemakmuran masyarakat sangat diutamakan bukan kemakmuran orang perseorangan. Maka dari itu, bentuk badan usaha yang tepat dalam hal ini adalah Koperasi.

Menurut UU No. 17 Tahun 2012, Koperasi adalah badan hukum yang didirikan oleh orang perseorangan atau badan hukum koperasi, dengan pemisahan kekayaan para anggotanya sebagai modal untuk menjalankan usaha, yang memenuhi aspirasi dan kebutuhan bersama di bidang ekonomi, sosial, dan budaya sesuai dengan nilai dan prinsip Koperasi.

Penilaian kinerja keuangan merupakan salah satu cara yang dapat dilakukan agar dapat memenuhi kewajibannya terhadap para penyandang dana dan juga untuk mencapai tujuan yang telah ditetapkan. Adapun alat analisis kinerja keuangan pada perusahaan yang digunakan meliputi : rasio likuiditas, rasio solvabilitas, rasio rentabilitas, rasio aktivitas, dan rasio pasar.

Dalam kegiatan usaha koperasi, agar berkembang dengan baik dituntut untuk menyusun laporan keuangan yang terdiri dari laporan laba rugi dan neraca. Untuk 
mengetahui apakah usaha yang dilakukan koperasi mengalami perkembangan, diadakan analisis mengenai faktor-faktor yang mendukung dalam pencapaian usaha. Salah satu faktor tersebut dapat dilihat dari analisis laporan keuangannya, yang terdiri dari analisis dengan menggunakan rasio likuiditas, solvabilitas, dan rentabilitas. Rasio likuiditas menggambarkan tingkat kemampuan koperasi untuk dapat memenuhi kewajiban atau membayar utang jangka pendeknya yang telah jatuh tempo. Rasio solvabilitas menggambarkan tingkat kemampuan koperasi untuk membayar semua utang-utangnya, baik jangka pendek maupun jangka panjang. Sementara rasio rentabilitas menggambarkan nilai kemampuan koperasi untuk mendapatkan laba (profit) dari pendapatan dan mencari keuntungan. Rasio rentabilitas juga memberikan ukuran tingkat efektifitas dalam manajemennya. Dengan diketahuinya analisis rasio likuiditas, solvabilitas, dan rentabilitas maka dapat diketahui kinerja keuangannya.

Analisis laporan keuangan untuk mengukur kinerja keuangan juga perlu dilakukan pada Koperasi Kredit Anugerah Bandarjaya, yang merupakan koperasi yang bergerak berdasarkan prinsip asas kekeluargaan. Koperasi Kredit Anugerah Bandarjaya terbuka untuk umum dan siapa saja yang ingin bergabung. Koperasi Kredit Anugerah Bandarjaya selain bertujuan untuk meningkatkan kesejahteraan anggota koperasi juga ingin mengembangkan usahanya lewat simpan pinjam yang sudah dilaksanakan sejak awal berdirinya koperasi.

Laporan keuangan yang digunakan oleh Koperasi Kredit Anugerah Bandarjaya dilaporkan keadaan dan kondisi keuangannya kepada pihak-pihak yang berkepentingan. Analisis atas laporan keuangan pada hakekatnya adalah untuk mengadakan penilaian atas keadaan keuangan pada Koperasi Kredit Anugerah Bandarjaya dan untuk mengetahui perkembangan serta kemajuan koperasi pada masa mendatang. Para pengurus koperasi dalam menjalankan kegiatannya perlu memperhatikan dan menjaga kondisi keuangan koperasi dengan baik. Namun dalam kurun waktu 3 tahun belakangan ini, Koperasi Kredit Anugerah Bandarjaya mengalami pembagian jumlah SHU yang kurang stabil pada setiap tahunnya. Berikut pembagian jumlah SHU Koperasi Kredit Anugerah selama tahun 2015-2017:

Selama 3 tahun terakhir, SHU dari Koperasi Kredit Anugerah Bandarjaya mengalami naik turun, terutama di tahun 2016 terjadi pembagian SHU yang mengalami penurunan cukup signifikan. Pembagian SHU berkaitan erat dengan rasio rentabilitas koperasi. Rasio rentabilitas koperasi dapat diketahui dengan memperbandingkan antara Sisa Hasil Usaha yang diperoleh dalam suatu periode dengan jumlah aktiva atau modal koperasi. Pembagian jumlah Sisa Hasil Usaha juga dipengaruhi oleh besarnya jumlah pinjaman anggota pada tahun yang bersangkutan. Masalah yang dihadapi oleh Koperasi Kredit Anugerah Bandarjaya ini adalah sering terjadinya kelalaian pinjaman dan peminjam yang tidak setia/macet. Hal ini juga mempengaruhi kinerja keuangan koperasi.

Mengingat perolehan Sisa Hasil Usaha selama tahun 2015 sampai dengan 2017 mengalami ketidakstabilan, maka untuk mengatasi hal tersebut perlu diadakan tindak lanjut atas kendala yang dihadapi.

\subsection{Perumusan Masalah}

1. Apakah Rasio Likuiditas berpengaruh terhadap pembagian Sisa Hasil Usaha (SHU) pada Koperasi Kredit Anugerah Bandarjaya Lampung Tengah?

2. Apakah Rasio Solvabilitas berpengaruh terhadap pembagian Sisa Hasil Usaha (SHU) pada Koperasi Kredit Anugerah Bandarjaya Lampung Tengah?

3. Apakah Rasio Rentabilitas berpengaruh terhadap pembagian Sisa Hasil Usaha (SHU) pada Koperasi Kredit Anugerah Bandarjaya Lampung Tengah?

4. Apakah Rasio Likuiditas, Solvabilitas, dan Rentabilitas berpengaruh terhadap pembagian Sisa Hasil Usaha (SHU) pada Koperasi Kredit Anugerah Bandarjaya Lampung Tengah? 


\subsection{Tujuan Penelitian}

1. Untuk menghitung pengaruh dari Rasio Likuiditas terhadap pembagian Sisa Hasil Usaha (SHU) pada Koperasi Kredit Anugerah Bandarjaya Lampung Tengah.

2. Untuk menghitung pengaruh dari Rasio Solvabilitas terhadap pembagian Sisa Hasil Usaha (SHU) pada Koperasi Kredit Anugerah Bandarjaya Lampung Tengah.

3. Untuk menghitung pengaruh dari Rasio Rentabilitas terhadap pembagian Sisa Hasil Usaha (SHU) pada Koperasi Kredit Anugerah Bandarjaya Lampung Tengah.

4. Untuk menghitung pengaruh dari Rasio Likuiditas, Solvabilitas, dan Rentabilitas terhadap pembagian Sisa Hasil Usaha (SHU) pada Koperasi Kredit Anugerah Bandarjaya Lampung Tengah.

\section{TINJAUAN PUSTAKA}

\subsection{Pengertian Laporan Keuangan}

Laporan Keuangan adalah hasil dari proses akuntansi yang dapat digunakan sebagai alat untuk berkomunikasi antara data keuangan atau aktivitas suatu perusahaan dengan pihak-pihak yang berkepentingan dengan data tersebut. Laporan keuangan merupakan salah satu alat untuk memperoleh informasi tentang kondisi keuangan dan hasil operasi suatu perusahaan.

Menurut Hanafi dan Halim (2016:49), menyatakan bahwa laporan keuangan merupakan salah satu sumber informasi yang penting disamping informasi lain, seperti: informasi industri, kondisi perekonomian, pangsa pasar perusahaan, kualitas manajemen dan lainnya. Pengertian lain menurut Kasmir (2014:7), "Laporan Keuangan adalah laporan yang menunjukkan kondisi keuangan perusahaan pada saat ini atau dalam suatu periode tertentu"

Laporan Keuangan dibuat dengan tujuan untuk menyampaikan informasi tentang kondisi keuangan perusahaan pada suatu saat tertentu kepada para pemangku kepentingan. Para pemakai laporan keuangan selanjutnya dapat menggunakan informasi tersebut sebagai dasar dalam memilih alternatif penggunaan sumber daya perusahaan yang terbatas (Samryn, 2012:33).
Menurut Kasmir (2012:66), pengertian Analisis Laporan Keuangan adalah: Penyusunan laporan keuangan berdasarkan data yang relevan, serta dilakukan dengan prosedur akuntansi dan penilaian yang benar, sehingga akan terlihat kondisi keuangan perusahaan yang sesungguhnya. Tujuan dan manfaat dari analisis laporan keuangan adalah untuk membuat keputusan yang rasional guna memenuhi tujuan perusahaan

Neraca merupakan suatu laporan yang menggambarkan keadaan perusahaan yang meliputi laporan aktiva, utang, dan modal yang terjadi selama periode akuntansi. Tujuan dibuatnya laporan keuangan neraca ini adalah untuk membantu investor, kreditur, dan pihakpihak lain yang membutuhkannya. Tujuan yang lebih spesifik adalah untuk memberikan informasi mengenai sumber daya ekonomi, kewajiban, modal dari suatu lembaga keuangan.

Menurut Kasmir (2016:28), "Laba Rugi (Income Statement) merupakan laporan keuangan yang menggambarkan hasil usaha perusahaan dalam suatu periode tertentu". Dalam laporan laba rugi ini tergambar jumlah pendapatan dan sumber-sumber pendapatan yang diperoleh. Kemudian juga tergambar biaya dan jenis-jenis biaya yang dikeluarkan selama periode tertentu.

Sedangkan Menurut Fahmi (2012:2), Kinerja Keuangan adalah suatu analisis yang dilakukan untuk melihat sejauh mana perusahaan telah melaksanakan dengan menggunakan aturan-aturan pelaksanaan keuangan secara baik dan benar seperti dalam membuat suatu laporan keuangan yang telah memenuhi standar atau ketentuan dalam SAK (Standar Akutansi Keuangan) atau GAAP (Generally Accepted Accounting Principle) dan lainnya".

\subsection{Jenis-Jenis Analisis Rasio Keuangan}

1. Rasio Likuiditas; Likuiditas sering digunakan oleh perusahaan maupun investor untuk mengetahui tingkat kemampuan perusahaan dalam memenuhi kewajibannya. Kewajiban tersebut bersifat jangka pendek. Semakin besar rasio 
lancar, maka likuiditas perusahaan dapat dikatakan semakin bagus.

Current Ratio $/$ Rasio Lancar $=\frac{\text { Aktiva Lancar }}{\text { Utang Lancar }} \times 100 \%$

2. Rasio Solvabilitas; Solvabilitas digunakan untuk mengukur kemampuan perusahaan dalam melunasi atau membayar semua kewajiban-kewajiban yang dimiliki oleh perusahaan. Pengertian rasio solvabilitas menurut Kasmir (2014:150) adalah Rasio yang digunakan untuk mengukur sejauh mana aktivitas perusahaan dibiayai dengan utang. Debt to Equity Ratio berpengaruh negatif terhadap pertumbuhan laba. Rasio Utang terhadap Modal/Debt to Equity Ratio (DER) dapat dihitung dengan menggunakan rumus:

Debt to Equity Ratio (DER) $=\frac{\text { Total Utang }}{\text { Total Modal }} \times 100 \%$

Debt to Equity Ratio (DER) dengan angka dibawah 1.00, mengindikasikan bahwa perusahaan memiliki utang yang lebih kecil dari modal (ekuitas) yang dimilikinya.

3. Rasio Rentabilitas; Rentabilitas atau bisa disebut juga dengan rasio Profitabilitas digunakan untuk mengukur keberhasilan perusahaan dalam memperoleh keuntungan pada tingkat penjualan, aset, dan modal yang ada. Return on Equity (ROE) dapat dihitung dengan menggunakan rumus sebagai berikut:

Return on Equity $(\mathrm{ROE})=\frac{\text { Laba Bersih }}{\text { Modal Sendiri }} \times 100 \%$

\subsection{Laporan Keuangan Koperasi}

Koperasi merupakan badan usaha yang beranggotakan orang-orang atau badan hukum koperasi dengan melandaskan kegiatannya berdasarkan prinsip koperasi sekaligus sebagai gerakan ekonomi rakyat yang berdasarkan asas kekeluargaan. Koperasi bertujuan untuk menyejahterakan anggotanya. Pengertian Koperasi menurut UU No. 17 Tahun 2012 Koperasi adalah badan hukum yang didirikan oleh orang perseorangan atau badan hukum koperasi, dengan pemisahan kekayaan para anggotanya sebagai modal menjalankan usaha, yang memenuhi aspirasi dan kebutuhan bersama di bidang ekonomi, sosial, dan budaya sesuai dengan nilai dan prinsip Koperasi.

Laporan Keuangan merupakan bagian dari laporan pertanggungjawaban pengurus tentang tata kehidupan koperasi. Tanggung jawab pengelolaan koperasi ada pada pengurus koperasi. Pengurus dipilih dari dan oleh anggota dalam suatu rapat anggota. Sebagai pertanggungjawaban atas pengelolaan koperasi, pengurus wajib untuk melaporkan kepada rapat anggota mengenai segala sesuatu yang berkaitan dengan tata kehidupan koperasi.

Laporan Keuangan Koperasi lebih ditujukan kepada pihak-pihak di luar pengurus koperasi dan bukan dimaksudkan untuk pengendalian usaha. Pihak-pihak pemakai laporan keuangan dibagi menjadi 2 (dua), yaitu: pihak utama yang meliputi para anggota serta para pejabat koperasi dan pemakai lainnya yang mempunyai kepentingan terhadap koperasi, diantaranya: calon anggota koperasi, kreditur, bank, dan kantor pajak.

\subsection{Sisa Hasil Usaha (SHU) Koperasi}

Koperasi tidak menggunakan istilah laba atau keuntungan untuk menunjukkan selisih antara penghasilan yang diterima selama periode tertentu dan pengorbanan yang dikeluarkan untuk memperoleh penghasilan itu. Selisih ini dalam koperasi disebut dengan Sisa Hasil Usaha (SHU).

Menurut Limbong (2012:138) pengertian Sisa Hasil Usaha adalah Sisa Hasil Usaha (SHU) koperasi adalah selisih dari seluruh pemasukan atau penerimaan total (total revenue/TR) dengan biaya-biaya atau biaya total (total cost/TC) dalam satu tahun buku.

Acuan dasar untuk membagi Sisa Hasil Usaha (SHU) adalah prinsip dasar koperasi yang menyebutkan bahwa pembagian Sisa Hasil Usaha (SHU) dilakukan secara adil sebanding dengan besarnya jasa usaha masing-masing anggota. Dengan demikian, SHU koperasi yang diterima oleh anggota bersumber dari dua kegiatan ekonomi yang dilakukan oleh anggota sendiri, yaitu SHU atau jasa modal dimana Pembagian ini juga sekaligus mencerminkan anggota sebagai 
pemilik ataupun investor, karena jasa atas modalnya (simpanan) tetap diterima dari koperasi sepanjang koperasi tersebut menghasilkan SHU pada tahun buku yang bersangkutan. SHU atas jasa modal, Jasa ini menegaskan bahwa anggota koperasi selain pemilik juga sebagai pemakai atau pelanggan.

\subsection{Hipotesis}

$\mathrm{H} 1$ : Rasio Likuiditas berpengaruh negatif terhadap pembagian Sisa Hasil Usaha (SHU) pada Koperasi Kredit Anugerah Bandarjaya Lampung Tengah.

$\mathrm{H} 2$ : Rasio Solvabilitas berpengaruh negatif terhadap pembagian Sisa Hasil Usaha (SHU) pada Koperasi Kredit Anugerah Bandarjaya Lampung Tengah.

H3: Rasio Rentabilitas berpengaruh negatif terhadap pembagian Sisa Hasil Usaha (SHU) pada Koperasi Kredit Anugerah Bandarjaya Lampung Tengah.

H4: Rasio Likuiditas, Solvabilitas, dan Rentabilitas berpengaruh negatif terhadap pembagian Sisa Hasil Usaha (SHU) pada Koperasi Kredit Anugerah Bandarjaya Lampung Tengah.

\section{METODE PENELITIAN}

\subsection{Jenis dan Sumber Data}

Dalam sebuah penelitian, untuk mendukung kelancaran dalam penyusunan laporan diperlukan data-data penelitian yang relevan dan akurat. Jenis data dalam penelitian dapat berupa data Kuantitatif dan data Kualitatif. Sumber Data adalah bagian yang akan menguraikan secara rinci tentang hal-hal yang ada hubungannya dengan jenis data dan teknik pengumpulan data.

Sumber Data yang digunakan dalam penelitian adalah menggunakan data sekunder. Data Sekunder adalah data yang telah dikumpulkan oleh lembaga pengumpul data dan dipublikasikan kepada masyarakat. Data sekunder tersedia melalui buku catatan keterangan yang berhubungan dengan penelitian yang sifatnya tidak langsung yang dapat dijadikan sebagai sumber informasi yang mendukung.

Data sekunder juga dapat berupa tabel, gambar, atau diagram yang dapat diperoleh dari hasil studi kepustakaan. Data sekunder yang penulis peroleh dalam penelitian ini yaitu data berupa buku Rapat Anggota Tahunan (RAT) yang terdapat Laporan Neraca, Laporan Laba Rugi, Laporan Sisa Hasil Usaha (SHU), Laporan Keuangan per bulan selama 3 (tiga) tahun, Laporan pinjaman anggota, dan juga data mengenai struktur organisasi Koperasi Kredit Anugerah Bandarjaya pada periode 2015 sampai dengan 2017.

\subsection{Teknik Pengumpulan dan Analisis Data Data}

Teknik Analisis Data merupakan salah satu cara yang digunakan untuk mengetahui sejauh mana variabel yang mempengaruhi variabel lain agar data yang dikumpulkan tersebut dapat bermanfaat. Sebelum melakukan uji linear berganda, metode mensyaratkan untuk melakukan uji asumsi klasik guna mendapatkan hasil yang terbaik. (Ghozali, 2011:105).

1. Uji Asumsi Klasik; dilakukan untuk mengetahui kelayakan penggunaan model dalam penelitian. Sebelum dilakukan pengujian hipotesis, data yang diperoleh dalam penelitian ini diuji terlebih dahulu untuk memenuhi asumsi dasar.

2. Uji Normalitas; dilakukan untuk menguji apakah variabel dependent dan independent dalam model regresi terdistribusi secara normal.

3. Uji Multikolinearitas; dilakukan untuk menguji apakah dalam model regresi ditemukan adanya hubungan antar variabel independent. Untuk mendeteksi ada atau tidaknya multikolinearitas data dapat dilihat dari nilai inflation factor (VIF). Jika nilai VIF di atas 10 , maka terjadi masalah multikolinearitas.

4. Uji Heteroskedastisitas; bertujuan untuk menguji ketidakseragaman varian dari residual antara suatu pengamatan dengan pengamatan lainnya, sedangkan keseragaman varian dari residual antara suatu pengamatan dengan pengamatan lainnya disebut Homoskedastisitas.

5. Uji Autokorelasi; bertujuan untuk menguji apakah dalam model regresi linear berganda ada korelasi antara kesalahan 
pengganggu pada periode $t$ dengan kesalahan pengganggu pada periode $\mathrm{t}-1$ (sebelumnya).

6. Uji t; Uji t digunakan untuk mengetahui seberapa jauh pengaruh variabel independent secara parsial terhadap variabel dependent.

7. Uji $\mathrm{F}$; digunakan untuk mengetahui apakah semua variabel independent yang dimasukkan dalam model mempunyai pengaruh secara simultan terhadap variabel dependent.

\subsection{Analisis Regresi Linear Berganda}

Persamaan regresi dalam penelitian ini adalah untuk mengetahui seberapa besar pengaruh variabel bebas (independent variable) yang dalam penelitian ini adalah Rasio Likuiditas $\left(X_{1}\right)$, Rasio Solvabilitas $\left(X_{2}\right)$, dan Rasio Rentabilitas $\left(X_{3}\right)$ terhadap variabel terikat (dependent variable) yang dalam penelitian ini adalah Pembagian Sisa Hasil Usaha (SHU) sebagai variabel $Y$. Rumus regresi linear berganda yang digunakan dalam penelitian ini adalah $\mathbf{Y}=\mathbf{a}+\mathrm{b}_{1} \mathrm{X}_{1}+\mathrm{b}_{2} \mathrm{X}_{2}+\mathrm{b}_{3} \mathrm{X}_{3}$ $+\mathrm{e}$

\section{HASIL PENELITIAN DAN PEMBAHASAN}

4.1 Uji Asumsi Klasik

1. Uji Normalitas

Gambar 1

Hasil Uji Normalitas

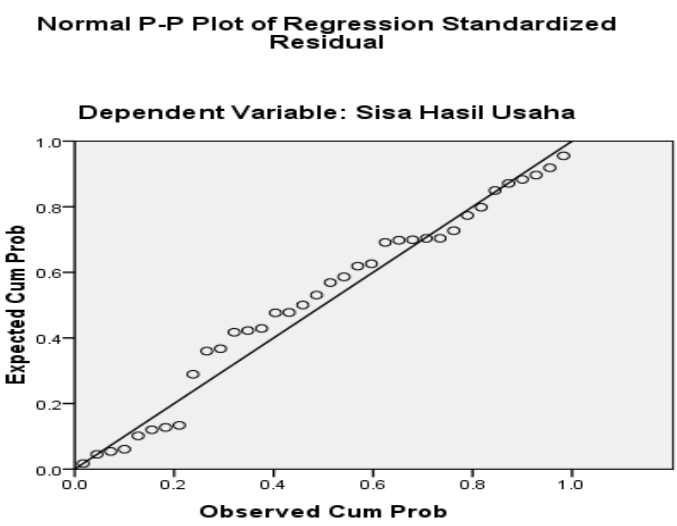

Sumber: Hasil Output SPSS 17

\section{Uji Multikolinearitas}

Tabel 1.

Hasil Uji Multikolinearitas

\begin{tabular}{|c|c|c|c|c|c|c|c|}
\hline \multirow{2}{*}{ Model } & \multicolumn{2}{|c|}{$\begin{array}{c}\text { Unstandardized } \\
\text { Coefficients }\end{array}$} & \multirow{2}{*}{$\begin{array}{c}\begin{array}{c}\text { Standardized } \\
\text { Coefficients }\end{array} \\
\text { Beta }\end{array}$} & \multirow{2}{*}{$\mathrm{T}$} & \multirow{2}{*}{ Sig. } & \multicolumn{2}{|c|}{$\begin{array}{l}\text { Collinearity } \\
\text { Statistics }\end{array}$} \\
\hline & B & $\begin{array}{l}\text { Std. } \\
\text { Error }\end{array}$ & & & & Tolerance & VIF \\
\hline (Constant) & -202.214 & 49.499 & & -4.085 & .000 & & \\
\hline 1 Rasio Likuiditas & 93.457 & 44.360 & .068 & 2.107 & .043 & .789 & 1.267 \\
\hline 1 Rasio Solvabilitas & 16.434 & 5.272 & .100 & 3.117 & .004 & .810 & 1.234 \\
\hline Rasio Rentabilitas & 1379.997 & 40.519 & 1.003 & 34.058 & .000 & .958 & 1.044 \\
\hline
\end{tabular}

Sumber: Hasil Output SPSS 17

3. Uji Heteroskedastisitas

Gambar 2.

Hasil Uji Heteroskedastisitas

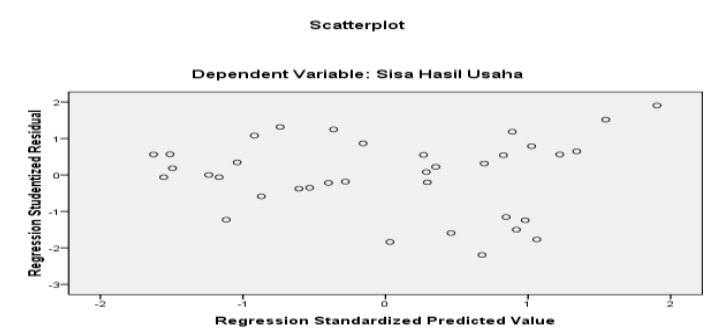

Sumber: Hasil Output SPSS 17

\section{Uji Autokorelasi}

Dari pengujian statistik diperoleh nilai Durbin-Waston sebesar 0,680 (DU = 1,6539 dan 4-DL = 2,7047). Hal ini berarti "tidak ada kesimpulan" pada model regresi, apakah terjadi atau tidak terjadi autokorelasi karena nilai DW tidak berada di antara nilai DU dan 4-DL. 
Tabel 2.

Hasil Uji Autokorelasi Model Summaryb

\begin{tabular}{lrrrrr}
\hline Model & R & R Square & Adjusted R Square & Std. Error of the Estimate & Durbin-Watson \\
\hline 1 & .987 a & .973 & .971 & 12.244 & .680 \\
\hline Sumber: Hasil Output SPSS 17 & & &
\end{tabular}

\section{$4.2 \mathrm{Ujit}$}

Tabel 3.

Hasil Uji t

\begin{tabular}{lrrrrrr}
\hline \multirow{2}{*}{ Model } & \multicolumn{2}{c}{$\begin{array}{l}\text { Unstandardized } \\
\text { Coefficients }\end{array}$} & \multicolumn{2}{c}{$\begin{array}{c}\text { Standardized } \\
\text { Coefficients }\end{array}$} & \multirow{2}{*}{$\mathrm{t}$} & \multirow{2}{*}{ Sig. } \\
\cline { 2 - 5 } & \multicolumn{1}{c}{$\mathrm{B}$} & Std. Error & \multicolumn{1}{c}{ Beta } & & & \\
\hline (Constant) & -202.214 & 49.499 & & -4.085 & .000 \\
\hline Rasio Likuiditas & 93.457 & 44.360 & .068 & 2.107 & .043 \\
\hline Rasio Solvabilitas & 16.434 & 5.272 & .100 & 3.117 & .004 \\
\hline Rasio Rentabilitas & 1379.997 & 40.519 & 1.003 & 34.058 & .000 \\
\hline
\end{tabular}

Sumber: Hasil Output SPSS 17

Berdasarkan tabel di atas, hasil uji $\mathrm{t}$ (parsial) menunjukkan bahwa:

1. Rasio Likuiditas (Current Ratio) memiliki nilai thitung 2,107 > tabel 1,688 (Tabel Persentase Distribusi $t$ ) dengan nilai signifikansi sebesar 0,043 $<0,05$ artinya Current Ratio (CR) memiliki pengaruh positif dan signifikan terhadap Pembagian Sisa Hasil Usaha (SHU) pada penelitian ini.

2. Rasio Solvabilitas (Debt to Equity Ratio) memiliki nilai thitung $3,117>t_{\text {tabel }} 1,688$ (Tabel Persentase Distribusi t) dengan nilai signifikansi sebesar $0,004<0,05$ artinya Debt to Equity Ratio (DER) memiliki pengaruh positif dan signifikan terhadap Pembagian Sisa Hasil Usaha (SHU) pada penelitian ini.

3. Rasio Rentabilitas (Return On Equity) memiliki nilai thitung $34,058>t_{\text {tabel }} 1,688$ (Tabel Persentase Distribusi t) dengan nilai signifikansi sebesar $0,000<0,05$ artinya Return On Equity (ROE) memiliki pengaruh positif dan signifikan terhadap Pembagian Sisa Hasil Usaha (SHU) pada penelitian ini.

\subsection{Uji F}

Uji $F$ digunakan untuk mengetahui apakah semua variabel independent yang dimasukkan dalam model mempunyai pengaruh secara simultan terhadap variabel dependent.

Tabel 4.

Hasil Uji F ANOVA ${ }^{b}$

\begin{tabular}{llrrrrr}
\hline \multicolumn{1}{l}{ Model } & Sum of Squares & Df & Mean Square & $F$ & \multicolumn{1}{c}{ Sig. } \\
\hline \multirow{2}{*}{1} & Regression & 175778.388 & 3 & 58592.796 & 390.865 & $.000^{\text {a }}$ \\
\cline { 2 - 7 } & Residual & 4796.974 & 32 & 149.905 & & \\
\cline { 2 - 7 } & Total & 180575.362 & 35 & & & \\
\hline
\end{tabular}

Sumber: Hasil Output SPSS 17 


\subsection{Uji Regresi Linear Berganda}

Tabel 5.

Hasil Uji Regresi Linear Berganda Coefficientsa

\begin{tabular}{|c|c|c|c|c|c|c|}
\hline \multirow{2}{*}{\multicolumn{2}{|c|}{ Model }} & \multicolumn{2}{|c|}{$\begin{array}{c}\text { Unstandardized } \\
\text { Coefficients }\end{array}$} & \multirow{2}{*}{$\begin{array}{c}\text { Standardized } \\
\text { Coefficients } \\
\text { Beta } \\
\end{array}$} & \multirow[t]{2}{*}{ T } & \multirow[t]{2}{*}{ Sig. } \\
\hline & & B & Std. Error & & & \\
\hline \multirow{4}{*}{1} & (Constant) & -202.214 & 49.499 & & -4.085 & .000 \\
\hline & Rasio L & 93.457 & 44.360 & .06 & 2.107 & .043 \\
\hline & Rasio Solvabilitas & 16.434 & 5.272 & .100 & 3.117 & .004 \\
\hline & Rasio Rentabilitas & 1379.997 & 40.519 & 1.003 & 34.058 & .000 \\
\hline
\end{tabular}

Sumber: Hasil Output SPSS 17

Berdasarkan nilai-nilai koefisien pada tabel di atas diperoleh persamaan sebagai berikut:

$$
\begin{aligned}
& Y=-202,214+93,457 X 1+16,434 X 2+ \\
& 1379,997 X 3
\end{aligned}
$$

\subsection{Uji Koefisien Determinasi $\left(R^{2}\right)$}

Tabel 6.

Hasil Uji Koefisien Determinasi Model Summaryb

\begin{tabular}{lrrrr}
\hline Model & R & R Square & Adjusted R Square & Std. Error of the Estimate \\
\hline 1 & $.987^{a}$ & .973 & .971 & 12.244 \\
\hline
\end{tabular}

Sumber: Hasil Output SPSS 17

Hasil uji koefisien determinasi $\left(\mathrm{R}^{2}\right)$ pada tabel di atas bernilai 0,973 . Hal ini menunjukkan bahwa Current Ratio (CR), Debt to Equity Ratio (DER), Return On Equity (ROE) mampu menjelaskan Sisa Hasil Usaha (SHU) sebesar $97,3 \%$ dan sisanya sebesar 2,7\% dijelaskan oleh variabel-variabel lain yang pada penelitian ini tidak diteliti

\section{SIMPULAN DAN SARAN}

\subsection{Simpulan}

1. Rasio Likuiditas (Current Ratio, Rasio Solvabilitas (Debt to Equity Ratio)dan Rasio Rentabilitas (Return On Equity) secara parsial berpengaruh positif dan signifikan terhadap Sisa Hasil Usaha (SHU).

2. Semua variabel independent, yaitu Rasio Likuiditas (Current Ratio), Rasio Solvabilitas (Debt to Equity Ratio), dan Rasio Rentabilitas (Return On Equity) secara bersama-sama (simultan) berpengaruh positif dan juga signifikan terhadap Sisa Hasil Usaha (SHU).

\subsection{Saran}

Diharapkan dari hasil penelitian ini dapat dijadikan sebagai tambahan informasi bagi koperasi untuk lebih meningkatkan kinerja dalam pengelolaan keuangannya Diharapkan bagi peneliti selanjutnya jika memilih acuan topik dan masalah penelitian yang sama, dapat memasukkan variabel lain yang dapat diteliti, seperti: Rasio Aktivitas, Rasio Pertumbuhan, dan Rasio Penilaian.

\section{DAFTAR PUSTAKA}

Albana, Isna Farah. 2015. Pengaruh Modal Sendiri dan Current Ratio Terhadap Sisa Hasil Usaha (SHU) di KPRI Kota Semarang Tahun 2013. Skripsi. Fakultas Ekonomi: Universitas Negeri Semarang.

Fahmi, Irham. 2012. Analisis Kinerja Keuangan. Alfabeta: Bandung.

Ghozali, Imam. 2011. Aplikasi Analisis Multivariate Dengan Program IBM SPSS 17. Cetakan Kelima. Badan Penerbit Universitas Diponegoro: Semarang. 
Ghozali, Imam. 2013. Aplikasi Analisis Multivariate Dengan Program SPSS. Edisi Ketujuh. Badan Penerbit Universitas Diponegoro: Semarang.

Hadi, M. Danar. 2013. Analisis Rasio Keuangan Yang Mempengaruhi Pertumbuhan Sisa Hasil Usaha (SHU) KPRI Dewantara di Kabupaten Jember. Skripsi. Fakultas Ekonomi: Universitas Jember.

Hanafi, Dr. Mamduh M., Prof. Dr. Abdul Halim. 2016. Analisis Laporan Keuangan. Edisi Ke - 5. UPP STIM YKPN: Yogyakarta.

Ikatan Akuntansi Indonesia. 2012. Standar Akuntansi Keuangan. Salemba Empat: Jakarta.

Jumingan. 2011. Analisa Laporan Keuangan. Cetakan ke - 4. Bumi Aksara: Bandung.

Kasmir. 2012. Analisis Laporan Keuangan. PT. Raja Grafindo Persada: Jakarta.

Kasmir. 2014. Analisis Laporan Keuangan (Edisi Pertama, Cetakan Ketujuh). PT. Raja Grafindo Persada: Jakarta.

Kasmir. 2016. Analisis Laporan Keuangan. PT. Raja Grafindo Persada: Jakarta.

Khotimah, Khusnul. 2015. Pengaruh Rasio Likuiditas, Solvabilitas, Rentabilitas, dan Pertumbuhan Modal Serta Kinerja Koperasi Terhadap Sisa Hasil Usaha Pada Koperasi Serba Usaha Daya Mentari Tegal. Jurnal Skripsi. Fakultas Ekonomi dan Bisnis: Universitas Dian Nuswantoro Semarang.

Limbong, Bernhard. 2012. Pengusaha Koperasi. Memperkokoh Fondasi Ekonomi Rakyat. Cetakan ke - 2. Margaretha Pustaka: Jakarta.
Munawir. 2012. Analisis Laporan Keuangan. Liberty: Yogyakarta.

Munawir. 2014. Analisis Laporan Keuangan. Liberty: Yogyakarta.

Padmautami Ni Kadek Ari, dkk. 2016. Analisis Rasio Keuangan Yang Mempengaruhi Pertumbuhan Sisa Hasil Usaha (SHU) di KSP Sari Apuan Denpasar. Disajikan dalam Seminar Nasional. Fakultas Ekonomi: Universitas Mahasaraswati Denpasar.

Peraturan Menteri Koperasi Dan Usaha Kecil Dan Menengah Republik Indonesia Nomor 12/Per/M.KUKM/IX/2015 tentang Pedoman Umum Akuntansi Koperasi Sektor Riil.

Rudianto. 2013. Akuntansi Manajemen. Erlangga: Jakarta.

Samryn. 2012. Pengantar Akuntansi. Mudah Membuat Jurnal Dengan Pendekatan Siklus Transaksi. Rajawali Pers: Jakarta.

Sudarwanto, Adenk. 2013. Akuntansi Koperasi. Pendekatan Praktis dan Penyusunan Laporan Keuangan. Graha IImu: Yogyakarta.

Sugiyono. 2012. Memahami Penelitian Kualitatif. Alfabeta: Bandung.

Supatmin. 2018. Analisis Pengaruh Likuiditas, Solvabilitas, dan Rentabilitas Terhadap Sisa Hasil Usaha Pada Koperasi Simpan Pinjam "PDW" Group. Jurnal Disrupsi Bisnis. Fakultas Ekonomi: Universitas Pamulang.

Undang-undang Republik Indonesia Nomor. 17 Tahun 2012 tanggal 29 Oktober 2012 tentang Perkoperasian. 